\title{
Modeling for Agriculture Irrigation Quality Index of the Iran in Southern Catchment Basin of Namak Lake Using Ad-Hoc, Expert Researches Awards Approach and Fuzzy-Statistical Methods
}

Javad Samadi ( $\sim$ javad_samadi_64@yahoo.com )

Shahid Beheshti University

\section{Short Report}

Keywords: Groundwater, Agriculture irrigation quality, AIQI index, Fuzzy-statistical method

Posted Date: March 1st, 2022

DOI: https://doi.org/10.21203/rs.3.rs-1381983/v1

License: (9) This work is licensed under a Creative Commons Attribution 4.0 International License.

Read Full License 


\section{Abstract}

Modeling and surveying the quality of agriculture irrigation is essential for management, site selection, land allocation and development of agriculture activities, water quality and quantity monitoring system, and protection of water resources and prevention the economic risks of agricultural products. In this study, following 15 parameters: Potential Salinity (PS), Electrical Conductivity (EC), Sodium Adsorption Ratio (SAR), Soluble Sodium Percentage (SSP), Kelly's Ratio (KR), Residual Sodium Carbonate (RSC), Magnesium Adsorption Ratio (MAR), Kalium Hazard (KH), Permeability Index (PI), Lime Deposition Potential (LDP), potential of Hydrogen $(\mathrm{pH})$, Total Hardness (TH), Bicarbonate Content (BC), ChloroAlkaline Indices (CAl) and Boron Hazard (BH), were used for spatial modeling of agriculture irrigation index. At first, very important and effective parameters on irrigation quality index were identified and the values of the parameters index based on research awards of experts and Ad Hoc system were rated using nonlinear regression and fuzzy-statistical methods. This was performed in such a way that the level and importance of each classes of classification parameters and the final model are considered equivalent and equal to the reclassified classes of agriculture irrigation quality index (AIQI) up to be equalized the parameters weight. The results showed that AIQI index based on the geometric mean of the parameters can demonstrate the highest impact on irrigation quality status and determining the agriculture suitable areas in catchment basin in south of the Namak Lake.

\section{Introduction:}

The reduction of groundwater quality and the enhancement of saltwater intrusion, in addition to destructions of economic, qualitative and quantitative to water resources can cause the most influence on agriculture. The sector that most water consumption is allocated i.e. on various agricultural activities, products, varieties and consequently on its economy. Paying attention to the appropriate locations of quality and chemical characteristics of agricultural irrigation, determining of products type and operation of farmlands, are some of the factors that can efficaciously help in reduction of water consumption, enhancement of varieties and economic efficiency of agricultural products. In many cases it has been observed that unsuitable site selection of irrigation quality has caused a destructive influence on agriculture sector.

In this regard, we can refer to numerous researches such as Ayers and Wescote (1985), Bauder et al (2010), Esmaeili vardanjani et al (2015), Hopkins et al (2007), Jafar ahamed et al (2013), Ravikumar et al. (2015) and Spectrum Analytic Incorporation (2015) that surveyed the hydro geochemical and qualitative parameters of groundwater (anions and cations) for preparation of manifold required indices, and classification and ranking these parameters for agriculture irrigation index. Nevertheless, the weaknesses of these indices were that, they didn't use the appropriate weights and rank for the irrigation quality modeling. Also did not use some of the important parameters, which lead to an incorrect estimation and unsuitable determination of irrigation quality and agriculture areas. 
Singh et al (2019) developed the irrigation water quality index on Bharalu river in Assam, India and suggest River Bharalu's irrigation suitability. Entropy weighted irrigation water quality index (EIWQI) was proposed and implemented on Bharalu River data for assessing its suitability and variability for irrigation. EIWQI less than 1 showed its appropriateness for irrigation owing to high value of RSC (5.45) and maximum entropy weight. Entropy weight of the parameters were in order RSC $>$ SAR $>B>E C$.

In addition, researches of Shafiullah \& Al-Ruwaih (2020), Abdel-Fattah et al (2020) and Khadr et al (2021) was performed for surveying the effect of parameters on the interpretation of irrigation quality using multivariate statistical methods.

Purposes and innovations this research include the following:

- Used all the parameters of hydro geochemical and required for determining of irrigation quality status and suitable areas

- Used opinions and research awards of experts for reviewing in the ranking and weighting of parameters and prepared of optimized new index according to geographical conditions of Iran

- Used nonlinear regression and fuzzy-statistical ranking in implementation of model geometric mean

\section{Case Study:}

Catchment basin in south of Namak (Salt) Lake is located in Kashan, Aran \& Bidgol cities on the hillside of Karkas mountain and Iran central desert margins. It is distanced about $240 \mathrm{~km}$ south of Tehran and $200 \mathrm{~km}$ away from north of Isfahan. It also has an area of $6950 \mathrm{~km}^{2}$ which is adjoined the Qom Plain from north, the adjacent heights of Natanz city and Meymeh city from south, the heights of Naraq city from the west, and Natanz city from east and is limited between $50^{\circ} 54^{\prime}$ to $52^{\circ} 6^{\prime}$ longitude and $34^{\circ} 30^{\prime}$ to $33^{\circ} 36^{\prime}$ latitude, with average rainfall of $154 \mathrm{~mm}$. This area has a maximum height of $3750 \mathrm{~m}$ in the southwest and minimum height of $755 \mathrm{~m}$ in the northern margin. About $58 \%$ of this area is characterized by a plain region with rainfall average of $118 \mathrm{~mm}$ in the northeastern half and about $42 \%$ of this area is located in mountainous region ( $2885 \mathrm{~km}^{2}$ area) with rainfall average of $205 \mathrm{~mm}$ in the southwest half. Majority of the water resources of these cities are groundwater.

\section{Materials And Methods:}

\section{3-1- The recommended system for modeling of agriculture irrigation quality:}

$\mathrm{AlQI}_{\mathrm{ssc}}{ }^{1}$ index is designed based on research opinions of experts and researchers which provides the water quality condition for agricultural consumptions in a quantitative form. It is a general and practical index for the introduction of water quality. 
This index is a simple and suitable tool for determination of the situation and the condition of agriculture water due to the natural condition, issues and problem facing of Iran water resources, which is associated with the data of the water quality for surface and sprinkler irrigation in a mathematical formula which showed the water quality. This number is classified by a relative scale which introduced the irrigationquality.

The main effective variable used in majority of agriculture irrigation quality indices, especially in considered modelling of this research be include : Electrical Conductivity (EC), Sodium Adsorption Ratio (SAR), Soluble Sodium Percentage (SSP), Kelly's Ratio (KR), Residual Sodium Carbonate (RSC), Magnesium Adsorption Ratio (MAR), Permeability Index (PI), potential of Hydrogen (pH), Total Hardness (TH), Potential Salinity (PS), Lime Deposition Potential (LDP), Kalium Hazard (KH), Bicarbonate Content (BC), Boron Hazard (BH), Chloro-Alkaline Indices (CAI), that are classified the criterion and the importance type of each of parameters as illustrated in table (1), according to the research awards of experts and $\mathrm{Ad}$ Hoc method on a recommended system.

For evaluation of irrigation quality, Eq. (1) was applied in this method which is required two factors for its achievement including: the qualitative amount and rating index for scaling (Table 1) of AIQI $\mathrm{SSC}_{\text {model }}$ parameters.

$$
\mathrm{AIQI}=\left[\prod_{i=1}^{\mathrm{N}} \mathrm{I}_{\mathrm{i}}\right]^{\frac{1}{\mathrm{n}}}(1
$$

$\mathrm{N}$ : number of parameters

$\mathrm{l}_{\mathrm{i}}$ : index value for i parameter from ranking curve.

The basis of preparing this model is the fact that effective parameters are considered as the ones restricting irrigation water quality and under non-standard conditions for each of parameters, it will be undesirable for the water that is intended as agriculture irrigation to be consumed. Also, as most of parameters have significant correlation with each other but with different effects, accordingly the geometric mean with equal weights has been implemented.

Considering the different conditions of geographical, hydrologic and hydro-geochemical in various regions, model parameters are used and prepared using statistical approaches commensurate with Iran's status, growth and quality of agriculture products and its limiting factors. Also are modified by the use of statistical methods for rating based on the related and similar researches, and awards of experts.

For scaling, according to the expert knowledge and by reclassified function, all the related criteria maps to irrigation quality are classified in two methods which are: deterministic and fuzzy-statistical. In deterministic method, the upper and lower range of classes of a code are considered according to ranking 
table (a value of 10 would indicate an area with the best and a value of 1 would indicate an area with the weakest operation as specified in drinking water quality model based on same parameter)

Table 1

Rating, weighting and range recommended system of model parameters of agriculture surface irrigation quality index

\begin{tabular}{|c|c|c|c|c|c|c|}
\hline \multicolumn{5}{|c|}{ Values rate and range of AIQI model parameters index } & \multirow[t]{2}{*}{ Unit } & \multirow[t]{2}{*}{ Parameters } \\
\hline$(1-3)$ & $(3-5)$ & $(5-7)$ & $(7-9)$ & $(9-10)$ & & \\
\hline $\begin{array}{l}\text { Very } \\
\text { unsuitable }\end{array}$ & Unsuitable & Allowable & Suitable & $\begin{array}{l}\text { Very } \\
\text { suitable }\end{array}$ & & \\
\hline$>700$ & $350-700$ & $150-350$ & $75-150$ & $0-75$ & ppm & PS \\
\hline$>6$ & $3-6$ & $1.5-3$ & $0.5-1.5$ & $0-0.5$ & $\mathrm{dS} / \mathrm{m}$ & EC \\
\hline $20-40$ & $12-20$ & $6-12$ & $3-6$ & $0-3$ & & SAR \\
\hline $80-100$ & $60-80$ & $40-60$ & $20-40$ & $0-20$ & $\%$ & SSP \\
\hline$>2$ & $1-2$ & $0.5-1$ & $0.25-0.50$ & $0-0.25$ & & $\mathrm{KR}$ \\
\hline$>5$ & $2.5-5$ & $1.25-2.50$ & $0-1.25$ & $<0.00$ & meq/L & RSC \\
\hline $80-100$ & $60-80$ & $40-60$ & $20-40$ & $0-20$ & $\%$ & MAR \\
\hline$>24$ & $12-24$ & $6-12$ & $3-6$ & $0-3$ & ppm & $\mathrm{KH}$ \\
\hline $0-10$ & $10-25$ & $25-50$ & $50-75$ & $75-100$ & $\%$ & $\mathrm{PI}$ \\
\hline$>7$ & $4.5-7$ & 3-4.5 & $1.5-3$ & $<1.5$ & $\mathrm{meq} / \mathrm{L}$ & LDP \\
\hline$<4 \&>10.2$ & $\begin{array}{l}4-5.2 \& 9- \\
10.2\end{array}$ & $\begin{array}{l}5.2-5.8 \& \\
8.4-9\end{array}$ & $\begin{array}{l}5.8-6.4 \& \\
7.8-8.4\end{array}$ & $6.4-7.8$ & & $\mathrm{pH}$ \\
\hline$>2$ & $1-2$ & $0.5-1$ & $0.2-0.5$ & $0-0.2$ & $\mathrm{~g} / \mathrm{L}$ & $\mathrm{TH}$ \\
\hline$>20$ & $8.5-20$ & $3-8.5$ & $1-3$ & $0-1$ & $\mathrm{meq} / \mathrm{L}$ & $\mathrm{BC}$ \\
\hline$>1 \&<-1$ & $( \pm 0.6)-( \pm 1)$ & $\begin{array}{l}( \pm 0.4)-( \pm \\
0.6)\end{array}$ & $( \pm 0.2)-( \pm 0.4)$ & $(0)-( \pm 0.2)$ & & CAI \\
\hline$>6$ & $3-6$ & $1.5-3$ & $0.5-1.5$ & $0-0.5$ & ppm & $\mathrm{BH}$ \\
\hline
\end{tabular}

In this study, nonlinear regression was used for fuzzification and statistical rating of parameters. In this method, it been tried to be surveyed the best regression line (obtained equations) according to the rank and amount of each of the parameters index of irrigation quality model (Fig. 2) In the next level, the criteria maps were incorporated into the obtained equations of this regression line and criteria layers of model parameters were scaled based on it. Then geometric mean of these maps was used for 
determining of agriculture irrigation quality level. The feature of this method is non-restriction on the use of all its parameters.

1. Agriculture Irrigation Quality Index for Surface and Sprinkler Irrigation-Conventional Parameters

\section{Results And Discussion:}

\section{4-1- parameters calculation and spatial modeling of AIQI index:}

Equations (2 to 12) displays the calculation method and preparation of parameters, and Figure (3) shows the model map of AIQI index based on interpolation of groundwater quality data (Kashan water resources affairs, 2002-2012; Kashan water \& wastewater company, 2002-2012) by Radial Basis FunctionsMultiquadric technique in ArcGIS 9.3 software environment.

$S A R=N a^{+} \mid \sqrt{\frac{C a^{2+}+M g^{2+}}{2}}(2$

$S S P=N a^{+} \times 100 /\left(\mathrm{Ca}^{2+}+\mathrm{Mg}^{2+}+\mathrm{Na}^{+}+\mathrm{K}^{+}\right)$

$K R=\mathrm{Na}^{+} /\left(\mathrm{Ca}^{2+}+\mathrm{Mg}^{2+}\right)(4$

$R S C=\left(\mathrm{CO}_{3}^{2-}+\mathrm{HCO}_{3}^{-}\right)-\left(\mathrm{Ca}^{2+}+\mathrm{Mg}^{2+}\right)(5$

$M A R=M g^{+2} \times 100 /\left(\mathrm{Ca}^{2+}+\mathrm{Mg}^{2+}\right)(6$

$P I=\left(\mathrm{Na}^{+}+\sqrt{\mathrm{HCO}_{3}^{-}}\right) \times 100 /\left(\mathrm{Ca}^{2+}+\mathrm{Mg}^{2+}+\mathrm{Na}^{+}\right)(7$

$T H=\left(2.497 \times C a^{2+}\right)+\left(4.11 \times M g^{2+}\right)(8$

$P S=\left(\mathrm{Cl}^{-}+\mathrm{SO}_{4}^{2-}\right) / 2(9$

$L D P=p H-p H_{C} \& p H_{C}=p\left(\mathrm{Ca}^{2+}+\mathrm{Mg}^{2+}+\mathrm{Na}^{+}+\mathrm{K}^{+}\right)$

$+p\left(\mathrm{Ca}^{2+}+\mathrm{Mg}^{2+}\right)+p\left(\mathrm{CO}_{3}^{2-}+\mathrm{HCO}_{3}^{-}\right)$ 
$C A I-I=\left(\mathrm{Cl}^{-}-\left(\mathrm{Na}^{+}+\mathrm{K}^{+}\right)\right) / \mathrm{Cl}^{-}$

$\mathrm{CAI}-\mathrm{II}=\frac{\mathrm{Cl}^{-}-\left(\mathrm{Na}^{+}+\mathrm{K}^{+}\right)}{\mathrm{SO}_{4}{ }^{2-}+\mathrm{HCO}_{3}^{-}+\mathrm{CO}_{3}^{2-}+\mathrm{NO}_{3}^{-}}$

According to Figure (3) the western and southern margins of catchments had appropriate agriculture irrigation quality and it is in allowable and suitable status due to rainfall and groundwater recharge. Kashan city is located in the allowable and critical area, Aran \& Bidgol city is located in an inappropriate area and the eastern parts of catchments which are located adjacent to Namak lake had a very unsuitable and inappropriate quality due to saltwater intrusion.

\section{Conclusion:}

These results are in line with the obtained results of previous similar studies (the literature review of the research). But the innovation of this research, in comparison with other similar studies, is utilizing fuzzystatistical rating of model parameters using nonlinear regression functions. Since this method was carried out using parameters real rate based on the results of studies and research awards of experts in Minitab 17 environment, error and uncertainty in calibration of parameters rating or in utilization of fuzzy logic for Fuzzification and non-deterministic (the maximum R2 of regression line) was minimized. It is possible to achieve better and more accurate results in the extent and value of the spatial significance of final model of irrigation.

Also, the parameters are provided in conditions that have the lowest collinearity and the most significance: if each of the parameters do not have the favorite standard for irrigation quality, it will be practically impossible for other parameters and the final model for successful and supplying desirable irrigation, hence the geometric mean of parameters index has been used.

\section{Declarations:}

\section{Compliance with ethical standards}

Conflict of interest: The author has declared no conflict and competing of interest

\section{References:}

1. Abdel-Fattah MK, Abd-Elmabod SK, Aldosari AA, Elrys AS, Mohamed ES. (2020) Multivariate Analysis for Assessing Irrigation Water Quality: A Case Study of the Bahr Mouise Canal, Eastern Nile Delta. Water, 12(9):2537.

2. Ayers RS, Westcot DW (1985) Water quality for agriculture. FAO irrigation and drainage paper. Food and Agriculture Organization of the United Nations Rome, 1985 ( ) FAO, 29 Rev. 1. 
3. Bauder TA, Waskom RM, Southerland PL, Davis JG (2010) Irrigation water quality criteria. Colorado State University, U.S. Department of Agriculture and Colorado counties cooperating, Fact Sheet No. 0.506.

4. Esmaeili vardanjani M, Rasa I, Amiri V, Yazdi M, Pazand K (2015) Evaluation of groundwater quality and assessment of scaling potential and corrosiveness of water samples in Kadkan aquifer, Khorasan-e-Razavi Province, Iran. Environmental Monitoring and Assessment, 53(2): 1-18.

5. Hopkins BG, Horneck DA, Stevens RG, Ellsworth JW, Sullivan DM (2007) Managing irrigation water quality for crop production in the Pacific northwest. Pacific Northwest Extension publication 597-E, $24 \mathrm{p}$.

6. Jafar ahamed A, Ananthakrishnan S, Loganathan K, Manikandan K (2013) Assessment of groundwater quality for irrigation use in Alathur Block, Perambalur district, Tamilnadu, south India. Applied Water Science, 3(4): 763-771.

7. Kashan Water and Wastewater Company. Groundwater Quality Parameters and Characteristics in Kashan, Aran \& Bidgol Cities; 2002-2012. Report No.: QC_3107.xIsx. (In Persian)

8. Kashan Water Resources Affairs. Hydrogeochemical characteristics in catchment basin in south of Namak lake; 2002-2012. Report No.: analiz zir.xlsx. (In Persian)

9. Khadr M, Gad M, El-Hendawy S, Al-Suhaibani N, Dewir YH, Tahir MU, Mubushar M, Elsayed S (2021) The Integration of Multivariate Statistical Approaches, Hyperspectral Reflectance, and Data-Driven Modeling for Assessing the Quality and Suitability of Groundwater for Irrigation. Water, 13(1):35.

10. Ravikumar P, Somashekar RK, Prakash KL (2015) Suitability assessment of deep groundwater for drinking and irrigation use in the parts of Hoskote and Malur Taluks, Karnataka (India). Environmental Research, Engineering and Management, 71(1): 15-26.

11. Shafiullah, G., Al-Ruwaih, F.M (2020) Spatial-multivariate statistical analyses to assess water quality for irrigation of the central part of Kuwait. Bull Eng Geol Environ 79, 27-37. https://doi.org/10.1007/s10064-019-01559-2

12. Singh, K.R., Goswami, A.P., Kalamdhad, A.S. et al. (2020) Development of irrigation water quality index incorporating information entropy. Environ Dev Sustain 22, 3119-3132. https://doi.org/10.1007/s10668-019-00338-z

13. Spectrum Analytic Incorporation (2015) Guide to interpreting irrigation water analysis. Washington C.H. Ohio, 20p.

\section{Figures}




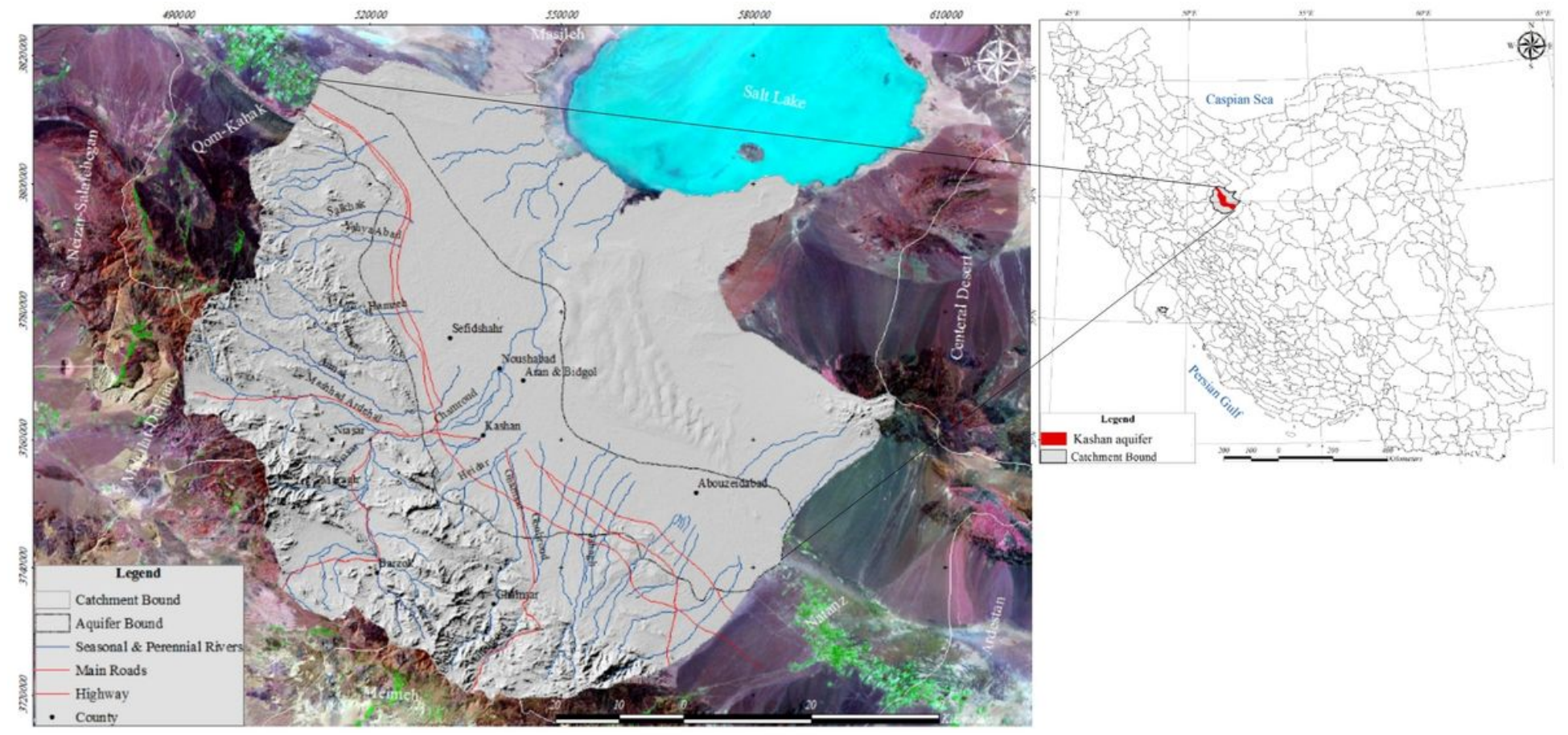

Figure 1

Map of study area (catchment basin in south of Namak lake) 

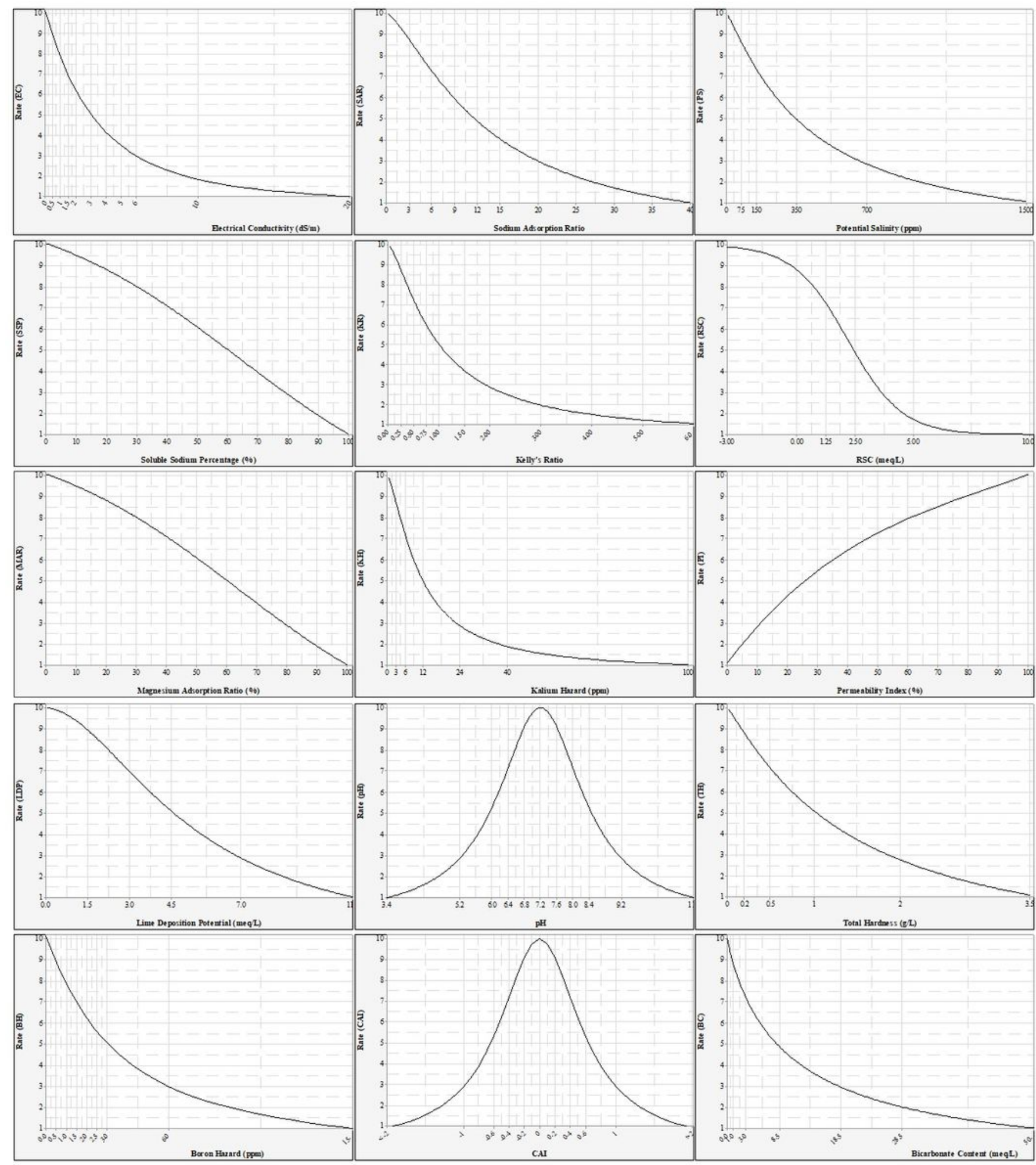

\section{Figure 2}

parameters Index values rating of agriculture surface irrigation quality 


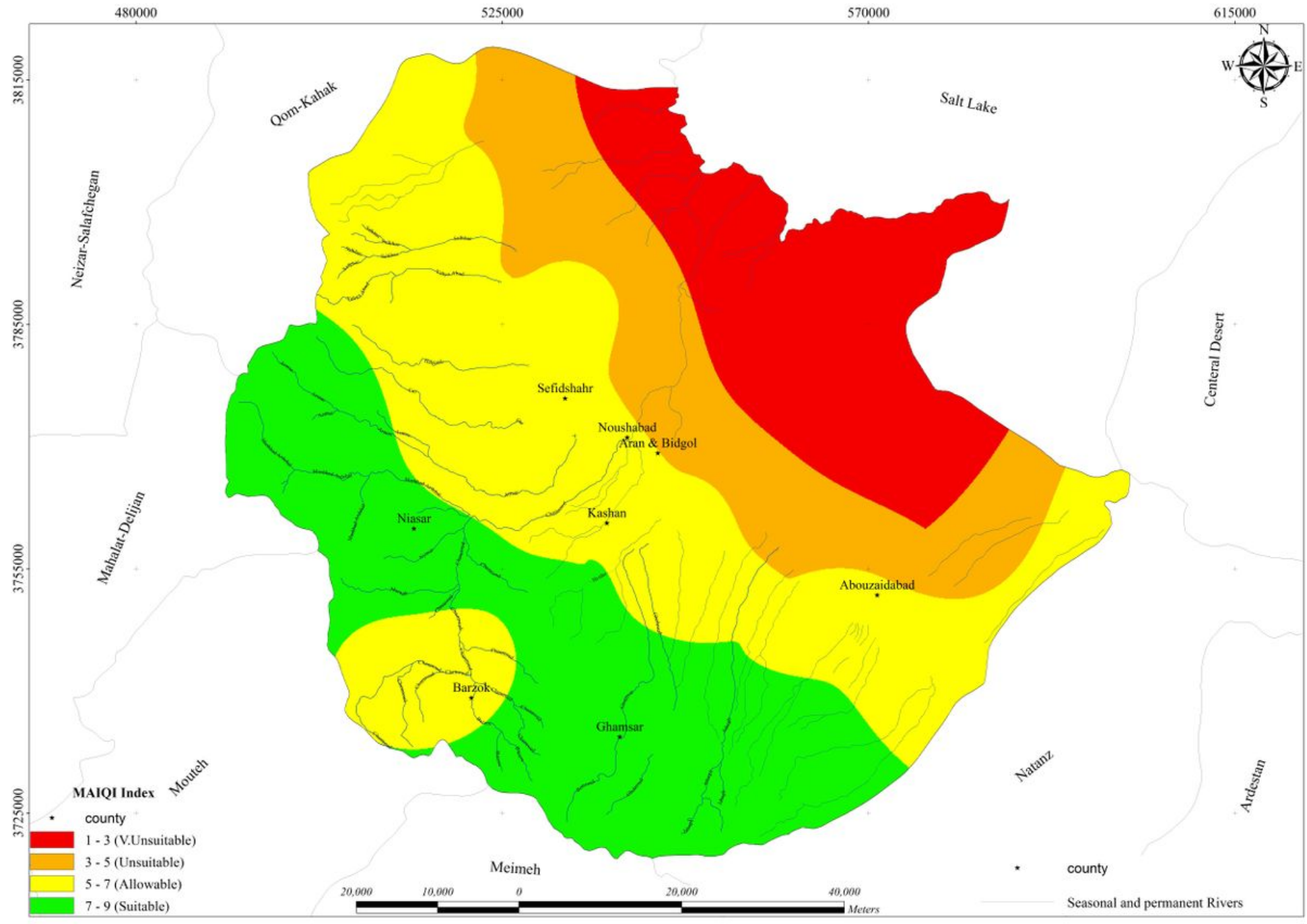

Figure 3

Map of agriculture surface irrigation quality index in study area 